\title{
AGENESIS OF THE POSTERIOR ARCH OF THE ATLAS: AN INCIDENTAL FINDING IN A POLYTRAUMATIZED PATIENT
}

\author{
AGENESIA DE ARCO POSTERIOR DE ATLAS: UM ACHADO ACIDENTAL EM UM PACIENTE \\ POLITRAUMATIZADO
}

\author{
AGENESIA DEL ARCO POSTERIOR DEL ATLAS: UN HALLAZGO INCIDENTAL EN UN \\ PACIENTE POLITRAUMATIZADO
}

Rodrigo Mota Pacheco Fernandes ${ }^{1}$, Lucas Alves Sarmento Pires ${ }^{1}$, Jorge Henrique Martins Manala ${ }^{1}$, Rafael Cisne de Paula ${ }^{1}$, Marcio Antonio Babinski

1. Universidade Federal Fluminense, Biomedical Institute, Department of Morphology, Niterói, RJ, Brazil.

\begin{abstract}
The first cervical vertebra is subject to numerous anatomical variations. One of these is posterior arch agenesis, which is classified into five distinct morphological types. Together, all types of posterior arch agenesis comprise only $4 \%$ of atlas variations. Furthermore, complete agenesis of the posterior arch associated with the presence of the posterior tubercle is rare. This work reports a case of posterior arch agenesis with the presence of the posterior tubercle in a 33 year-old male victim of a motor vehicle collision. Despite being asymptomatic, this anatomical variation can present with headaches and neck pain. It is mostly found as an incidental finding in imaging studies performed by the emergency team and, as a result, it is often misdiagnosed as a C1 fracture. Knowledge of the variations relating to the first cervical vertebra is therefore essential to avoid delays in diagnosis and treatment of polytraumatized patients. Level of evidence $\mathbf{V}$; Case report.
\end{abstract}

Keywords: Cervical atlas; Congenital abnormalities; Multiple trauma; Anatomic variation.

\section{RESUMO}

A primeira vértebra cervical é alvo de inúmeras variações anatômicas. Uma destas inclui a agenesia do seu arco posterior, que é classificada em cinco tipos morfológicos distintos. Apesar de uma incidência de 4\% na população em geral, a agenesia completa do arco posterior, associada à presença do tubérculo posterior do atlas, é rara. Objetivou-se no presente trabalho relatar a agenesia completa do arco posterior com a presença do tubérculo posterior da primeira vértebra cervical em um paciente de 33 anos de idade, que sofreu um acidente automobilístico. Em geral, essa condição é assintomática, porém, essa variação anatômica pode causar sintomas como dores de cabeça. Na maioria dos casos, é um achado acidental em exames de imagem realizados pela equipe de emergência. Como resultado, a agenesia de arco posterior de atlas pode ser interpretada erroneamente como uma fratura. Portanto, o conhecimento das variações anatômicas da primeira vértebra cervical é essencial para evitar erro no diagnóstico e tratamento de pacientes politraumatizados. Nível de Evidência V; Relato de caso.

Descritores: Atlas cervical; Anormalidades congênitas; Traumatismo múltiple; Variação anatômica.

\section{RESUMEN}

La primera vértebra cervical puede presentar numerosas variaciones anatómicas. Una de ellas es la agenesia del arco posterior, que se clasifica en cinco tipos morfológicos distintos. En conjunto, todos los tipos de agenesia del arco posterior comprenden solo el $4 \%$ de las variaciones del atlas. Además, la agenesia completa del arco posterior asociada con la presencia del tubérculo posterior es rara. Este trabajo relata un caso de agenesia del arco posterior con presencia del tubérculo posterior en un paciente del sexo masculino de 33 años de edad que sufrió un accidente automovilístico. A pesar de ser asintomática, esta variación anatómica puede causar dolores de cabeza y cuello. Se encontra principalmente como hallazgo incidental en pruebas de imagen realizadas por el equipo de emergencia y como resultado, a menudo se diagnostica erróneamente como una fractura de C1. El conocimiento de las variaciones anatómicas de la primera vértebra cervical es, por lo tanto, esencial para evitar retrasos en el diagnóstico y tratamiento de pacientes politraumatizados. Nivel de Evidencia V; Relato de caso.

Descriptores: Atlas cervical; Anomalías congénitas; Traumatismo múltiple; Variación anatómica.

\section{INTRODUCTION}

The first cervical vertebra (Atlas) is situated between the occipital bone and the second cervical vertebra (Axis). It is one of the main components of head movement, due to its joints, and it serves as an attachment for several muscles. ${ }^{1}$

Anatomical variations of this vertebra are known in the literature. ${ }^{1,2}$
Despite this, radiological assessment of living patients is uncommon, and some variations can be misinterpreted as fractures, causing confusion among physicians. . $^{3-5}$

This work reports a case of agenesis of the posterior arch of $\mathrm{C} 1$, which was presented as an incidental finding in a polytraumatized patient. 


\section{CASE REPORT}

This study was conducted in accordance with the Declaration of Helsinki, and the patient signed an informed consent form.

A 33 year-old male patient was admitted to an emergency service following a motor vehicle collision. Although asymptomatic, he was submitted to the standard protocol for polytraumatized patients.

Radiological investigation showed a change in the cervical region: there was no continuity between the posterior tubercle of the atlas and its lateral masses. (Figure 1) Further examination showed that this condition was not caused by the trauma, as the patient had developed no symptoms whatsoever.

The patient signed an informed consent form, and is not identified in this manuscript.

\section{DISCUSSION}

During embryogenesis, the caudal half of the first cervical scleretome fuses with the cranial half of the second cervical sclerotome,

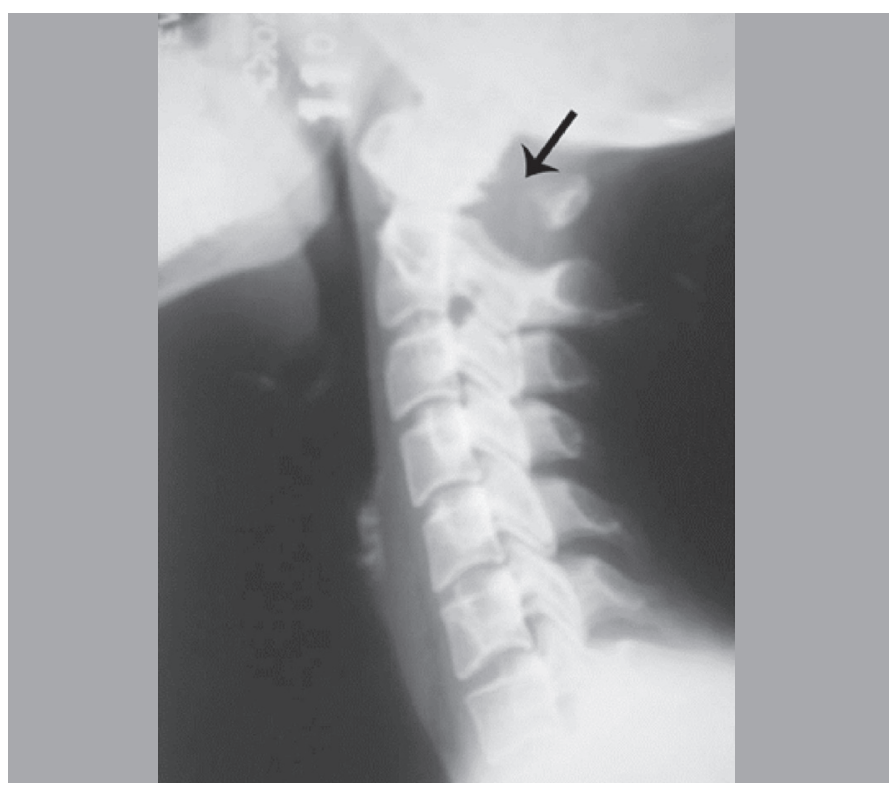

Figure 1. Lateral x-ray of the cervical column. The lack of posterior arch and presence of the posterior tubercle of the atlas can be seen (black arrow). thus giving origin to the first cervical vertebrae. ${ }^{6}$ The atlas then undergoes endochondral ossification and possesses three ossification centers: two of these will form the lateral masses, while the remaining central one will give rise the dens of the axis. ${ }^{1}$

The lamina originates from the lateral masses and expands dorsally to form the posterior arch of the atlas. In rare cases, the right and left laminae fail to fuse, leaving the posterior tubercle of the atlas isolated, a condition known as posterior arch agenesis. ${ }^{1,5,7}$ A secondary ossification center usually appears for the posterior tubercle. . $^{1,7}$

The atlas also may be subject to numerous variations, such as its occipital assimilation, duplication, anterior arch agenesis, or even a bipartite atlas. ${ }^{2,5}$

There are five distinct types of posterior arch agenesis, classified according to the form of fusion (A, B, C, D and E). The case presented herein is classified as Type $D$, described as "Absence of the posterior arch with persistent posterior tubercle". ${ }^{3}$

Posterior arch agenesis is a fairly uncommon condition that affects $4 \%$ of the general population. ${ }^{5}$ However, this prevalence refers to all posterior arch clefts, including minor defects, although some authors observe a prevalence of $0.69 \%$ for types C, D and E combined. ${ }^{8}$

An analysis of CT scans performed by Junewick et al. (2011) ${ }^{9}$ did not find a single case of type D. Furthermore, there are only a few reports of complete agenesis of the posterior arch with the presence of the posterior tubercle..$^{3,8,10-16} \mathrm{~A}$ summary of these cases is given in Table 1.

Clinically, posterior arch agenesis is usually asymptomatic. There have been reports of symptoms such as intermittent tetraparesis, cervical pain, headache, and Lhermitte's sign, although these may be attributable to the trauma. ${ }^{5,17}$ The main concern for physicians is misdiagnosis of a fracture in cases of posterior arch agenesis, since it is mostly discovered as an incidental finding. ${ }^{7,9,17}$

Despite the rare prevalence of the variation presented herein, anomalies of the first cervical vertebra are not uncommon. Hence, knowledge of the atlas variations are significant for healthcare professionals who deal with trauma or radiological studies, in order to avoid misdiagnosis

All authors declare no potential conflict of interest related to this article.

Table 1. Summary of similar reported cases.

\begin{tabular}{|c|c|c|c|c|c|}
\hline Author & Sex & Age & Type $^{3}$ & Symptoms & Other congenital anomalies \\
\hline Castãno-Duque et al. $(1997)^{10}$ & Female & 63 & D & Cervicalgia and "seasickness" & None reported \\
\hline \multirow{2}{*}{ Sharma et al. $(2000)^{16}$} & Female & 32 & D & Pain and spinal stenosis & None reported \\
\hline & Female & 35 & D & $\begin{array}{l}\text { Neck pain and weakness in the upper } \\
\text { limbs }\end{array}$ & None reported \\
\hline Panagopoulos et al. (2005) & Male & 24 & D & Neck pain & None reported \\
\hline Sagiuchi et al. $(2006)^{14}$ & Male & 26 & D & $\begin{array}{l}\text { Lhermitte's sign after yawning due to } \\
\text { compression of the spinal cord by the } \\
\text { posterior tubercle }\end{array}$ & None reported \\
\hline Sahoo et al. $(2018)^{15}$ & Female & 17 & $\mathrm{D}$ & Progressive spastic quadriparesis & None reported \\
\hline
\end{tabular}


CONTRIBUTION OF THE AUTHORS: Each author made significant individual contributions to this manuscript. RMPF (0000-0003-0481-6528)* attended the patient initially, and performed the exams. JHMM (0000-0002-0403-5417), LASP (0000-0002-2756-1794)* and MAB (0000-0001-7988-1071)* gathered clinical data and conducted the survey RMPF, JHMM, LASP, RCP (0000-0002-4624-3935) and MAB reviewed the manuscript and contributed to the intellectual concept of the study. All the authors approved the final version of the manuscript. *ORCID (Open Researcher and Contributor ID).

\section{REFERENCES}

1. Testut L, Latarjet A. Tratado de Anatomia Humana. Barcelona: Salvat; 1958.

2. Tubbs RS, Shoja MM, Loukas M. Bergman's Comprehensive Encyclopedia of Human Anatomic Variation. New Jersey: John Wiley \& Sons; 2016.

3. Currarino G, Rollins N, Diehl JT. Congenital Defects of the Posterior Arch of the Atlas: A Report of Seven Cases Including an Affected Mother and Son. AJNR Am J Neuroradiol. 1994;15(2):249-54.

4. Offiah CE, Day E. The craniocervical junction: embryology, anatomy, biomechanics and imaging in blunt trauma. Insights Imaging. 2017;8(1):29-47.

5. ParkY, Kim SM, LeeYT, Yoo JH, Oh HC, Ha JW, et al. Congenital anomaly of the atlas misdiagnosed as posterior arch fracture of the atlas and atlantoaxial subluxation. Clin Orthop Surg. 2014;6(1):96-100.

6. Schoenwolf G, Bleyl S, Brauer P, Francis-West P. Larsen's Human Embryology. 5th ed. London:Churchill Livingstone; 2014

7. Torriani M, Lourenço JLG. Agenesis of the posterior arch of the atlas. Rev Hosp Clin Fac Med S Paulo. 2002;57(2):73-6

8. Panagopoulos A, Zouboulis P, Athanaselis E, Papadopoulos AX, Dimakopoulos P. Aplasia of the posterior arc of the atlas with persistent posterior tubercle: a case report. Eur Spine J. 2005;14(2):205-7.

9. Junewick JJ, Chin MS, Meesa IR, Ghori S, Boynton SJ, Luttenton CR. Ossification patterns of the atlas vertebra. AJR Am J Roentgenol. 2011;197(5):1229-34.

10. Castaño-Duque CH, Rivas-García A, Pons-Irazazabal LC, López-Moreno JL. [Partial bilate- ral agenesis of the posterior arch of the atlas]. Rev Neurol. 1997:25(148):1928-31.

11. Jensen $U$, Stohring $C$, Werner $P$, Jansen $O$. Partial aplasia of the posterior arch of the atlas with a persistent posterior tubercle. Clin Neuroradiol. 2010;20(3):175-7.

12. Klimo Jr P, Blumenthal DT, Couldwell WT. Congenital partial aplasia of the posterior arch of the atlas causing myelopathy: case report and review of the literature. Spine (Phila Pa 1976). 2003;28(12):E224-8.

13. Png W, Hey HW, Mohan K, Yue WM. Congenital absence of the posterior arch of the atlas with concomitant fusion to the axis: a case report. J Orthop Surg (Hong Kong). 2015;23(3):402-4

14. Sagiuchi T, Tachibana S, Sato K, Shimizu S, Kobayashi I, Oka H, et al. Lhermitte sign during yawning associated with congenital partial aplasia of the posterior arch of the atlas. AJNR Am J Neuroradiol. 2006;27(2):258-60.

15. Sahoo S, Salunke P, Karthigeyan M, Rajasekhar R. "Suspended PosteriorTubercle of Atlas" with Atlantoaxial Dislocation. World Neurosurg. 2018;113:37-9.

16. Sharma A, Gaikwad SB, Deol PS, Mishra NK, Kale SS. Partial aplasia of the posterior arch of the atlas with an isolated posterior arch remnant: findings in three cases. AJNR Am J Neuroradiol. 2000;21(6):1167-71.

17. Sabuncuoglu H, Ozdogan S, Karadag D, Timurkaynak E. Congenital Hypoplasia of the Posterior Arch of the Atlas: Case Report and Extensive Review of the Literature. Turk Neurosurg. 2011;21(1):97-103 